\title{
On the role of sensitised T-lymphocytes in the pathogenesis of multiple sclerosis
}

\author{
A L A N T U RER, M L C UZNER, A N D A VISON, A N D \\ P E T E R R U D E \\ From the Department of Neurochemistry, Institute of Neurology, and National Hospital for \\ Nervous Diseases, Queen Square, London
}

SUMMARY Peripheral blood lymphocytes from 24 out of 26 patients with clinically welldefined multiple sclerosis in remission showed sensitisation to multiple sclerosis brain extracts as assayed by enhancement of the early erythrocyte rosette test. Such an increase in the number of early rosettes was not found when the lymphocytes of multiple sclerosis patients were exposed to extracts of control brains. In contrast the sensitised cells were found in the circulation in only two of 11 patients with multiple sclerosis in acute relapse. The percentage of circulating T-lymphocytes which formed early rosettes was lower in the group of patients suffering a relapse than in patients in remission. A longitudinal study of one patient who was tested before, during and after a relapse revealed the disappearance from the blood of the sensitised T-cells during the relapse and their subsequent reappearance after recovery. Of 36 patients with other neurological diseases, two responded solely to multiple sclerosis brain, two responded to both multiple sclerosis and control brain, and three responded only to control brain. No healthy controls showed sensitisation to any brain extract.

There is evidence to suggest that T-cell dependent cell mediated immunity may contribute to the pathogenesis of multiple sclerosis. ${ }^{1}$ Offner et $a l,{ }^{2}$ using the test of enhancement of early rosettes, showed specific sensitisation of peripheral blood lymphocytes from multiple sclerosis patients to multiple sclerosis brain extracts. In view of the important implications for the pathogenesis and treatment of multiple sclerosis we attempted to reproduce their findings, extending the range of neurological controls, and examining the proportion of early rosette forming cells and the sensitisation at different stages in the course of the disease.

The marker of the human thymus-dependent (T) lymphocyte used is its ability to bind sheep red blood cells (SRBC) to the cell surface in the form of a rosette. A sub-population of T-cells has been identified with very high affinity for $\mathrm{SRBC}^{3}$; they are known variously as "active T-cells" or "early rosetting T-cells" because they form

Address for reprint requests: Dr A Turner, lnstitute of Neurology, Queen Square, London WC1N 3BG.

Accerted 30 November 1979 rosettes very rapidly. The early rosette test was adapted by Felsburg and Edelman ${ }^{4}$ as a sensitive marker of cell-mediated immunocompetence; they found that the early rosette count in patients with delayed cutaneous hypersensitivity was increased when the antigen to which the patient was hypersensitive was incubated with the lymphocytes in vitro.

\section{Patients and methods}

Peripheral blood was taken from 83 people. The different groups were: (i) multiple sclerosis patients in remission $(n=26$. Mean age 36 years $)$, (ii) multiple sclerosis patients in relapse $(n=11$. Mean age 34 years), (iii) patients with other neurological diseases ( $n=36$ years. Mean age 43 years), (iv) healthy volunteers $(n=10$. Mean age 33 years). All multiple sclerosis patients were diagnosed as clinically certain according to the criteria of McAlpine. ${ }^{5}$ None of the patients or controls was on immunosuppressant treatment. One of the patients with subacute sclerosing panencephalitis had recently been treated with transfer factor. The 
other neurological diseases were: meningoencephalitis (2), cerebrovascular accident (7), peripheral neuropathy, optic neuritis (2), intracerebral tumour (4), tension headache, cerebral sarcoidosis, trigeminal neuralgia, epilepsy, Parkinson's discase, normal pressure hydrocephalus, cerebral metastases (primary unknown), neurosyphilis, acoustic neuroma, pre-senile dementia, intracranial meningioma, Guillain-Barré syndrome, tuberculous meningitis, motor neurone disease, spinal cord lesion (aetiology unknown), sub-acute sclerosing panencephalitis (2), carpal tunnel syndrome, system degeneration (unknown cause), and proximal myopathy.

\section{Brain homogenates}

Tissue samples consisting of approximately equal proportions of white and grey matter were dissected from four brains with histologically confirmed MS and from three control brains. Post mortem time in each case was no greater than 24 hours and the brains were stored at $-70^{\circ} \mathrm{C}$. Twenty-five per cent $(w / v)$ homogenates were prepared in $0.14 \mathrm{M} \mathrm{NaCl}$ at $4^{\circ} \mathrm{C}$ and centrifuged at $1000 \mathrm{~g}$ for $25 \mathrm{~min}$. The supernatants were stored in small aliquots at $-70^{\circ} \mathrm{C}$. Separate aliquots were used for each assay and appropriate dilutions made immediately before use. Protein was determined by the method of Lowry et al. ${ }^{6}$

\section{Active $E$ rosette test}

The early rosette forming cells were assayed by the method described by Offner et al. ${ }^{2}$ Briefly, blood was taken from a peripheral vein on the same morning as the test and transferred to a lithium heparin tube (Labco). Lymphocytes were isolated on a Lymphoprep gradient, washed three times with medium 199 and resuspended $\left(4 \times 10^{\text {s }}\right.$ cells per $\mathrm{ml}$ ) in medium 199 containing $25 \%$ foetal calf serum (heat-inactivated and sheep red blood cell adsorbed). Sheep red blood cells (Tissue Culture Services Ltd, Slough), were washed three times with medium 199 and suspended in medium 199 to a concentration of $60 \times 10^{6}$ cells $/ \mathrm{ml}$. For each test $0.25 \mathrm{ml}$ aliquots of lymphocyte suspension were pipetted into glass test tubes $(12 \times 75 \mathrm{~mm})$, $10 \mu$ lof medium 199 containing brain antigen was added and the tubes incubated at room temperature $\left(20^{\circ} \mathrm{C}\right)$ for $15 \mathrm{~min}$. Appropriate controls with no added brain antigen were included.

After the incubation $0.25 \mathrm{ml}$ of sheep red blood cells were added and the test tubes were centrifuged at $100 \mathrm{~g}$ for exactly $3 \mathrm{~min} .0 .25 \mathrm{ml}$ of supernatant was removed and replaced by $2 \%$ crystal violet in saline. Resuspension was performed by rotating the test tubes gently for $3 \mathrm{~min}$ in a machine. ${ }^{7}$ After resuspension a sample was drawn up by passive capillary action into a Pasteur pipette and then transferred onto a counting chamber. In counting, the whole of the grid was surveyed and at least 200 cells enumerated. Each sample was run in duplicate. Cell viability, determined by trypan blue exclusion, was always more than $90 \%$. At the time of reading the slides the samples were coded so that the observer did not know whether the cells were from a test tube with control medium or multiple sclerosis brain or control brain. A lymphocyte with three or more adherent sheep red blood cells was considered to be a rosette.

Methods of expressing the results

The early rosette forming T-cells (ERFC), and antigen-stimulated early rosette forming $T$-cells (Ag-ERFC) are expressed as the percentage of lymphocytes which formed rosettes. The sensitisation of the T-cells is expressed as the ratios of Ag-ERFC to ERFC. The level of significance was calculated by Student's $t$ test.

The percentage of early rosettes was confirmed on each duplicated sample by repeat measurement three hours later. Repeated measurements on two of the authors did not change over six months, and three patients with multiple sclerosis in remission were each tested on three different days, weeks apart, during which time their percentage of early rosettes did not alter significantly.

\section{Results}

Dose-response experiments showed that the optimum concentration of multiple sclerosis brain supernatant giving the maximum increase in early rosette-forming cells was $2 \cdot 3 \mu \mathrm{g}$ protein $/ 0.25 \mathrm{ml}$ of lymphocyte suspension. The increase was still significant but of less magnitude at concentrations of $23 \mu \mathrm{g}$ and $0.23 \mu \mathrm{g}$ protein.

\section{Early rosette forming $T$-cells}

There is no significant difference in the mean percentage of early rosette forming cells between healthy controls, patients with other neurological diseases, and patients with multiple sclerosis in remission (table 1). The mean percentage of early rosette forming cells in patients with a relapse of multiple sclerosis $(27 \cdot 3 \%)$ is significantly lower $(p<0.005)$ than in patients in remission of the disease $(38.0 \%)$ and even more significantly $(p<0.001)$ lower than that for healthy controls $(41.7 \%)$ and other neurological diseases $(43 \cdot 1 \%)$. 
Table 1 Percentage of early rosette forming cells with and without added brain extract

\begin{tabular}{|c|c|c|c|c|c|c|c|}
\hline Group & No & $\begin{array}{l}\% \text { early } \\
T \text {-cells } \\
\text { mean } \pm S D \\
A\end{array}$ & $\begin{array}{l}\% \text { early } T \text {-cells } \\
w / M S \text { brain } \\
\text { extract } \\
\text { mean } \pm S D \\
B\end{array}$ & $\begin{array}{l}\text { Stimulated ratio } \\
w / M S \text { brain } \\
\text { mean } \pm S D \\
B: A\end{array}$ & $\begin{array}{l}\text { No patients } \\
\text { positive } \\
w / M S \text { brain }\end{array}$ & $\begin{array}{l}\text { Stimulated ratio } \\
w / \text { control brain } \\
\text { mean } \pm S D\end{array}$ & $\begin{array}{l}\text { No patients } \\
\text { positive } \\
\text { w/control } \\
\text { brain }\end{array}$ \\
\hline $\begin{array}{l}\text { I Multiple sclerosis in remission } \\
\text { II Multiple sclerosis in relapse } \\
\text { II I Healthy controls } \\
\text { IV Other neurological disorders }\end{array}$ & $\begin{array}{l}26 \\
11 \\
10 \\
36\end{array}$ & $\begin{array}{l}38 \cdot 0 \pm 10 \cdot 1 \\
27 \cdot 3 \pm 7 \cdot 1 \dagger \\
46 \cdot 1 \pm 9 \cdot 9 \\
43 \cdot 6 \pm 8 \cdot 5\end{array}$ & $\begin{array}{l}48 \cdot 5 \pm 9 \cdot 8 \\
27 \cdot 9 \pm 8 \cdot 1 \\
41 \cdot 7 \pm 10 \cdot 7 \\
43 \cdot 1 \pm 9 \cdot 1\end{array}$ & $\begin{array}{l}1 \cdot 31 \pm 0 \cdot 20^{*} \\
1.01 \pm 0 \cdot 14 \\
0.91 \pm 0 \cdot 11 \\
0.99 \pm 0 \cdot 13\end{array}$ & $\begin{array}{r}24 \\
2 \\
0 \\
4\end{array}$ & $\begin{array}{l}0.99 \pm 0.12 \\
0.98 \pm 0.12 \\
0.88 \pm 0.12 \\
0.99 \pm 0.14\end{array}$ & $\begin{array}{l}2 \\
1 \\
0 \\
5\end{array}$ \\
\hline
\end{tabular}

$*=$ Significance of difference from all other stimulated ratios: $p<0.001$.

$\dagger=$ Significance of difference from Group $1: p<0.005$ and Groups III and IV $p<0.001$.

\section{Antigen-stimulated early rosette forming $T$-celis $(A g-E R F C)$}

Incubation of lymphocytes from multiple sclerosis patients in remission with four different human multiple sclerosis brain extracts resulted in an increase in the percentage of early rosette forming cells. Ag-ERFC/ERFC was $1 \cdot 31$, which is significantly different $(p<0.001)$ from the figure of 0.99 for the ratio calculated when control brain antigen was added to lymphocytes from multiple sclerosis patients. All four multiple sclerosis brain extracts produced the increase in different patients (table 2) and one patient was tested with all of the extracts and the ratios were $1.65,1.25,1.34$ and 1.32 . Neither multiple sclerosis brain nor control brain extract produced significant increases in the $\mathrm{Ag}$ ERFC/ERFC ratio of multiple sclerosis patients in relapse, of other neurological diseases or healthy controls.

Considering the results of individuals, Felsburg and Edelman ${ }^{4}$ found that a $15 \%$ increase of Ag-ERFC over ERFC was significant, that is, the Ag-ERFC/ERFC ratio was greater than 1.15 in patients with cellular hypersensitivity, and not so in controls. Of the patients with multiple sclerosis in remission 24 of the 26 had a ratio of Ag-ERFC/ ERFC of greater than $1 \cdot 15$. The two patients who did not respond to multiple sclerosis brain also showed no enhancement with control brain and two patients with multiple sclerosis in remission responded to control brain. Of the 11 patients in relapse of multiple sclerosis only two showed a response to MS brain and one of those two re- sponded also to control brain. Healthy controls did not respond to any brain extract. Two patients with intracerebral tumours responded both to multiple sclerosis brain and to control brain; one patient with an intracerebral tumour and one with epilepsy, phenytoin-induced osteomalacia and proximal myopathy responded only to multiple sclerosis brain. One patient with subacute sclerosing panencephalitis, one with a recent stroke, and one with system degeneration of unknown cause responded only to control brain.

A longitudinal study in a 22 year old woman with multiple sclerosis shows that in the first test, when she had only minor symptoms of brain stem disorder, her T-lymphocytes showed a marked sensitivity to multiple sclerosis brain. When next seen, one month later, she had been unable to walk for a week with what was judged clinically to have been an episode of brain stem demyelination; the number of circulating early $T$-cells had dropped but the cells still showed sensitisation. Five days later her early T-cells had dropped to $10 \%$ and the sensitisation had disappeared. She gradually improved clinically over the next few weeks and ultimately made an excellent recovery. As can be seen from the figure it took over two months for the ERFC percentage to return to its former level and for sensitisation to return.

\section{Discussion}

Although there have been conflicting reports on changes in total circulating $\mathrm{T}$-cells there is some

Table 2 Ratios for different brain extracts of stimulated T-cells to early $T$-cells of multiple sclerosis patients in remission

\begin{tabular}{|c|c|c|c|c|c|}
\hline$M S$ brain & $\begin{array}{l}\text { No of } M S \\
\text { patients tested }\end{array}$ & $\begin{array}{l}\text { Ratio } \\
\text { mean } \pm S D\end{array}$ & $\begin{array}{l}\text { Control } \\
\text { brain }\end{array}$ & $\begin{array}{l}\text { No of MS } \\
\text { patients tested }\end{array}$ & $\begin{array}{l}\text { Ratio } \\
\text { mean } \pm S D\end{array}$ \\
\hline $\begin{array}{l}\text { A } \\
\text { B } \\
\text { C } \\
\text { D }\end{array}$ & $\begin{array}{r}4 \\
4 \\
13 \\
5\end{array}$ & $\begin{array}{l}1 \cdot 46 \pm 0 \cdot 27 \\
1 \cdot 30 \pm 0 \cdot 31 \\
1 \cdot 25 \pm 0 \cdot 16 \\
1 \cdot 31 \pm 0 \cdot 26\end{array}$ & $\begin{array}{l}E \\
F \\
G\end{array}$ & $\begin{array}{r}11 \\
7 \\
6\end{array}$ & $\begin{array}{l}0.99 \pm 0.12 \\
1.02 \pm 0.11 \\
0.99 \pm 0.11\end{array}$ \\
\hline
\end{tabular}




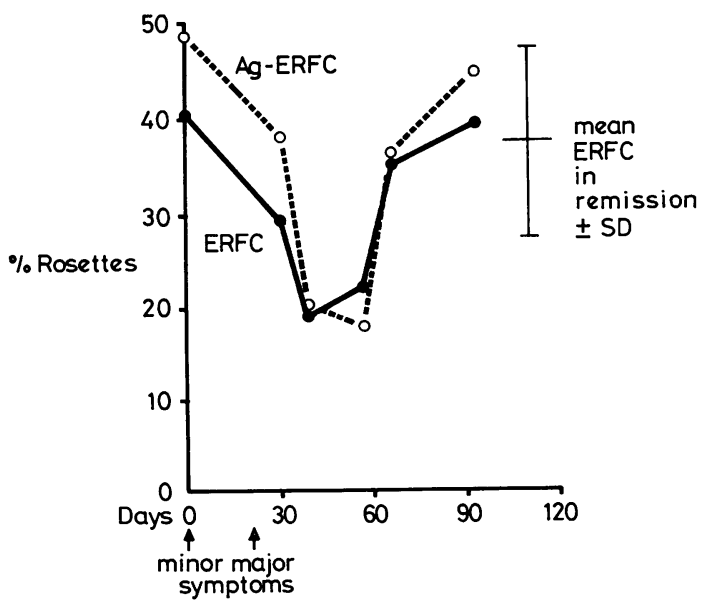

Figure Percentage of early $(E R F C)$ rosettes $(O)$ and early rosettes $(A g-E R F C)$ in the presence of multiple sclerosis brain $(O)$ extract in a patient tested during and after a relapse.

evidence that early $\mathrm{T}$-cells are reduced in the blood of multiple sclerosis patients. ${ }^{89}$

We have found that reduction in the proportion of early T-cells is only significant during a relapse, thus agreeing with concurrent findings of Traugott et al. ${ }^{8}$ Moreover during a relapse $\mathrm{T}$-cells are not activated by added extract of MS brain. As shown by Offner and her colleagues, ${ }^{27}$ however, there is a significant increase in the early rosette forming $\mathrm{T}$-cells when the extract is added to lymphocytes from multiple sclerosis patients in remission.

These observations are of particular interest for circulating T-lymphocytes have previously been shown to be sensitised to myelin basic protein $^{81011} 12$ but the effect seems to be less specific than the uncharacterised antigen derived from the post nuclear supernatant of multiple sclerosis brain and the sensitisation is not so clearly related to the disease status of the patient. Recently Offner and colleagues ${ }^{13}$ have found lymphocytes of all multiple sclerosis patients, but none with other neurological diseases, responded to a partially purified fraction of multiple sclerosis brain.

In a preliminary longitudinal study (figure) we found that at the beginning of an attack there was a slow reduction in the proportion of active T-cells in the circulation and paralleling the relapse a loss of sensitivity to added multiple sclerosis brain antigen.

We consider that there is a striking resemblance between the changes in early $\mathrm{T}$-cell populations during the course of multiple sclerosis and changes seen in guinea pigs with experimental allergic encephalomyelitis, a known cell-mediated demyelinating disease. Prior to the onset of clinical signs of experimental allergic encephalomyelitis there is a marked increase of circulating early $T$ cells ${ }^{14}$ and a $\mathrm{T}$-cell sensitivity to basic protein as revealed by enhancement of the early rosette test. ${ }^{15}$ There follows an abrupt decrease when the animals develop clinical signs just before death, while circulating total T-cells and B-cells show little change. ${ }^{14}$ Cells recovered from the meninges and surface of the spinal cord show a higher percentage of early rosette-forming cells than the peripheral blood of normal guinea pigs, suggesting that there has been a migration of early T-cells from the circulation into the CNS at the time of relapse. ${ }^{16}$ During a relapse it has been repeatedly observed that there is an increase in total T-cells in the CSF 171819 although these may not be predominantly early rosetting T-cells. ${ }^{20}$

On the basis of our findings, therefore, it is rational to use immunosuppressant therapy against T-cells of the type already found to be successful in the treatment of experimental allergic encephalomyelitis.

We thank Dr PC Gautier-Smith and other neurological colleagues at the National Hospital, and Dr $\mathbf{H}$ Valdimarsson at St Mary's Hospital, and Dr G Agnaradottir at the Royal Postgraduate Medical School for allowing us to study their patients.

This research was supported by a grant from the Multiple Sclerosis Society.

We are grateful to Professor CWM Adams for supplying brains from the MRC MS Tissue Bank at Guy's Hospital.

\section{References}

1 Knight SC. Cellular immunity in multiple sclerosis. Brit Med Bull 1977; 33:45-50.

2 Offner H, Rastogi SC, Konat G, Clausen J. The enhancing effect of multiple sclerosis brain homogenates on the active E-rosette forming lymphocytes. J Neurol 1978; 218:245-51.

3 Wybran J, Fudenberg HH. Thymus derived rosette-forming cells. $N$ Engl J Med 1973; 288: 1072-3.

4 Felsberg PJ, Edelman R. The active E-rosette test: a sensitive in vitro correlate for human delayed-type hypersensitivity. J Immunol 1977; 118:62-6.

5 McAlpine D. In: McAlpine D, Lumsden CE, Acheson ED. Multiple sclerosis: a reappraisal, 2nd ed. Edinburgh: Churchill Livingstone, 19:81307. 
6 Lowry OH, Rosenbrough NJ, Farr AL, Rundell FJ. Protein measurement with the Folin reagent. J Biol Chem 1951; 193:285-71.

7 Offner H, Fog T, Rastogi SC, Konat G, Clausen J. The enhancing effect of multiple sclerosis brain homogenates on the active E-rosette forming lymphocytes in neurological disorders. Acta Neurol Scand 1979; 59:49-54.

8 Traugott U, Scheinberg LC, Raine CS. Multiple sclerosis: circulating antigen-reactive lymphocytes. In press, Ann Neurol $\mathbf{9 9 0}$.

9 Kateley JR, Bazzell SJ. Immunological dysfunctions in multiple sclerosis. I. Diminution of 'active' thymus-derived lymphocytes and presence of immunomodulating serum factors. Clin Exp Immunol 1979; 35:218-26.

10 Offner H, Konat G, Raun NE, Clausen J. E rosette-forming lymphocytes in multiple sclerosis patients. Basic protein stimulation of rosetteforming cells. Acta Neurol Scand 1978; 57:380-4.

11 Colby-Germinario SP, Sheremata W, Bain B, Eyler EH. Studies of cellular sensitization to myelin antigens in multiple sclerosis. J Neurol Sci 1977; 33:111-29.

12 Hashim GA, Lee DH, Pierce JC, Braun CW, Fitzpatrick HF. Myelin basic protein-stimulated rosette-forming $\mathbf{T}$ cells in multiple sclerosis. Neurochem Res 1978; 3:37-48.

13 Offner H, Rastogi SC, Konat G, Clausen J. Stimu- lation of active $\mathrm{E}$ rosette forming lymphocytes by myelin basic protein and specific antigens from multiple sclerosis brains. J Neuro! Sci 1979; 47: 349-55.

14 Traugott U, Raine CS. Experimental allergic encephalitis in inbred guinea pigs: correlation of decrease in early $T$ cells with clinical signs in suppressed and unsuppressed animals. Cell Immunol 1977; 34:146-55.

15 Hashim GA, Lee DH, Pierce JC. Antigenstimulated rosette formation by $\mathrm{T}$ lymphocytes in experimental allergic encephalomyelitis. Neurochem Res 1977; 2:99-109.

16 Traugott $\mathrm{H}$, Stone SH, Raine CS. Experimental allergic encephalomyelitis: migration of early $\mathbf{T}$ cells from the circulation into the central nervous system. J Neurol Sci 1978; 36:55-61.

17 Naess A, Nyland H. T lymphocytes in cerebrospinal fluid and blood. Eur Neurol 1978; 17:61-6.

18 Traugott H. T and B lymphocytes in the cerebrospinal fluid of various neurological diseases. J Neurol 1978; 185-97.

19 Allen JC, Sheremata W, Cosgrove JBR, Osterland $K$, Shea $M$. Cerebrospinal fluid $T$ and $B$ lymphocyte kinetics related to exacerbations of multiple sclerosis. Neurology 1976; 26:579-83.

20 Kam-Hansen S. Reduced active T cell subpopulation in multiple sclerosis cerebrospinal fluid. Acta Neurol Scand 1978; 57, suppl 67:242. 